\title{
LA MÚSICA INSONORA DEL FONDO ADALID O LA INVISIBILIDAD DE LA PRÁCTICA MUSICAL DOMÉSTICA MASCULINA DE LA ÉLITE DURANTE LA RESTAURACIÓN' ${ }^{1}$
}

\author{
Carolina Queipo Gutiérrez \\ Universidad de La Rioja
}

\begin{abstract}
RESUMEN: Durante la época de la Restauración europea (ca.1815-1848), los Adalid y los Torres, familias de comerciantes alto-burgueses emparentadas entre sí y residentes en la ciudad de A Coruña, invirtieron gran parte de la fortuna familiar en la adquisición de una educación correspondiente a su estatus social, en dónde la música ocupaba un puesto principal. Dos grandes colecciones de partituras documentan esa inversión cultural junto con otras fuentes como cuadros, cartas, documentos notariales, libros de comercio, facturas, etc. Partiendo de la discusión sobre si puede considerarse música un fondo de partituras como el de la familia Adalid, caracterizado por la escasa presencia de marcas visibles que denoten la existencia de una práctica musical, con el presente ensayo demostraremos por un lado que en este tipo de colecciones las marcas de ejecución no son ni mucho menos objeto definitorio de su sonoridad. Por otro lado probaremos que colecciones como esta ofrecen lecturas diferentes sobre la cuestión "qué es música" relacionadas con la representatividad social, cultural y económica de la música, en este caso de un grupo de varones ricos y poderosos de la España de la Restauración absolutista.
\end{abstract}

Palabras clave: Sonoridad e insonoridad, coleccionismo, práctica musical doméstica, música de cámara, música seria, élite social, música e imagen, masculinidad.

1. Este artículo forma parte de la tesis doctoral en curso que la autora está desarrollando en la Universidad de La Rioja bajo la dirección de la doctora Teresa Cascudo García-Villaraco. La autora desea dar expresamente las gracias al Instituto de Estudios Riojanos (IER) por contribuir al desarrollo de esta investigación a través de la concesión de una beca. 


\title{
SOUNDLESS MUSIC OF THE ADALID COLLECTION OR THE INVISIBILITY OF DOMESTIC MUSIC-MAKING OF MALE ELITE SOCIETY DURING THE RESTORATION PERIOD
}

\begin{abstract}
During the period of European Restoration (ca. 1815-1848), the Adalids and the Torres, two related upper-bourgeois merchant families resident in the city of Corunna, used a major part of the family fortune to achieve the cultural level consistent with their social status, which included music as a principal element. Two great score collections provide the documentary evidence for this cultural investment together with pictures, letters, notary records, accounting books, bills, etc. We start with a discussion of whether it is possible to consider a score collection such as the Adalid Collection to be music, a question that arises due to the scarcity of visible marks denoting the existence of music-making in the scores. Consequently, the first aim of the present text is to demonstrate that in this kind of collection the performance marks in the scores are far from being the determining criteria of whether the pieces were actually performed. In addition, we will show that a collection with the characteristics of the one that is the object of our study, gives the question "what is music?" a different interpretation, closer to the social, cultural and economic representation of music, in this case, of a wealthy and powerful group of men of Restoration period Spain.
\end{abstract}

Keywords: Performance and soundless music, collecting, domestic music-making, chamber music, serious music, upper-class music, music and image, male music.

\section{Introducción}

El fondo de partituras Adalid se encuentra actualmente en la Biblioteca da Real Academia Galega (BRAG) de A Coruña y contiene dos mil setecientas veintinueve piezas musicales ${ }^{2}$. Se divide principalmente en dos grandes series conforme al periodo en el cual las partituras fueron editadas y coleccionadas por miembros del clan Adalid en generaciones sucesivas ${ }^{3}$. En la primera serie, que es en la que

2. Boletín de la BRAG, año XXIV, 212, (1-1-1929). Por otro lado, tanto el fondo musical como las colecciones de libros familiares, aparecen inventariados en un documento conservado en la BRAG (sign. 02.38.1.20/6) que lleva por título Libro $3^{\circ}$, Biblioteca, Índices de los documentos y efectos de la casa y propiedades de $D^{a}$ María de los Dolores del Adalid de Ruiz de Ruidobro.

3. En el momento de la llegada del fondo a la BRAG, el archivero de esta institución no distinguió las series de colecciones de partituras que fueron compradas por los miembros de diferentes generaciones de la familia Adalid. Creemos que tampoco hizo un recuento correcto del número de obras. La labor de nuestro trabajo ha sido, entre otras cosas, seleccionar las obras que pertenecieron a sus diferentes miembros. Hemos llegado a contabilizar dos grandes series con divisiones internas que forman a su vez subseries. 
está basado nuestro estudio, se contabilizan en torno a seiscientas cincuenta obras $^{4}$. Estas fueron impresas por firmas editoriales extranjeras entre ca. 1815 y 1827 y compradas y encuadernadas entre 1826 y 1827 por Juan Antonio (A Coruña, 1795; A Coruña, 1848) y su hermano Francisco del Adalid y Loredo (A Coruña, 1792; A Coruña, 1855), miembros de la segunda generación del clan Adalid -véase Gráfico 1 con el árbol genealógico- ${ }^{5}$. En esta serie prevalece ostensiblemente la música de cámara instrumental con un 75\% de ocupación, siendo las piezas más numerosas las que relacionamos con el movimiento idealista musical y a las que nos referiremos a lo largo de este trabajo bajo el término de música de cámara "sabia" o "seria" ${ }^{\text {. }}$ La sección siguiente, según el número de obras, es la

Las piezas musicales se organizan por sets de volúmenes encuadernados. En un mismo volumen se recogen diferentes piezas pertenecientes a una misma parte instrumental, de tal forma que un set dedicado al cuarteto de cuerda lo forman cuatro volúmenes y cada uno de ellos recoge una de las cuatro partes instrumentales. La encuadernación fue hecha en A Coruña en la imprenta de Arza, en los años de 1826 y 1827 según figura en las etiquetas que llevan cada uno de los volúmenes que forman los sets.

4. Para más información sobre los creadores de la colección musical, sobre la historia y características de las partituras del propio fondo y sobre otras cuestiones de catalogación véanse Queipo Gutiérrez, Carolina, "Boccherini, Haydn, Beethoven in Restoration Spain: a Study on the Reception of Chamber Music Works", en Boccherini Studies, Christian Speck (ed.), Bolonia, Ut Orpheus Edizioni, Vol 5, en prensa. Íd. "El fondo musical Adalid y las prácticas musicales domésticas de la élite social urbana de la Restauración europea", en Revista de Musicología, en prensa.

5. Marcial Francisco Adalid de Rozas y Ramírez de Arellano (Nestares, 1755; A Coruña, 1822), es el patriarca de la saga Adalid en A Coruña. Oriundo de Tierra de Cameros (La Rioja) llegó a A Coruña a finales del siglo XVIII.

6. La sección de música de cámara instrumental de esta serie de partituras del fondo Adalid está formada principalmente por un repertorio musical homogéneo de obras para conjunto de cámara instrumental de instrumentos de cuerda, viento o de ambos, con o sin piano o guitarra y organizados en cuartetos, quintetos, dúos, tríos, sextetos y septetos. El cuarteto de cuerda es el formato más numeroso en el fondo.

Los conceptos de movimiento idealista musical -musical idealism- y música de cámara "seria" están tomados de los estudios de William Weber y el término "música sabia" de Judith Etzion. Los repertorios de conciertos propios del idealismo musical se formaron en Europa durante la etapa de la Restauración. Las obras de estos repertorios estaban dedicadas al conjunto instrumental de cámara (cuartetos, quintetos, dúos, tríos, sextetos, septetos...) u orquestal, y pertenecen a autores fundamentalmente clásicos pero también modernos (coetáneos al acto de interpretación de sus obras) que emulaban la música de aquellos clásicos -véase el párrafo del texto relacionado con la nota 17 dónde aportamos más información sobre el concepto idealismo musical-. Por otro lado, hacia 1830 el término de música "seria" empezó a hacerse más común para identificar un repertorio de concierto propio del movimiento idealista musical y para diferenciarse del repertorio comercial, denominado como música "ligera", cada vez más creciente y predominante (Weber, William, The Great Transformation of Musical Taste: Concert Programming from Haydn to Brahms, New York, Cambridge University Press, 2008, pp. 92-101, 122-125 y 176-177). El concepto de "música sabia" funciona, en términos generales, como sinónimo de "seria" en su aplicación sobre el contexto cultural y social de la España de la primera mitad del siglo XIX. Etzion, Judith, "'Música Sabia': The Reception of Classical Music in Madrid (18301860)", en International Journal of Musicology, VII (1998), pp. 185-231. 
CAROLINA QUEIPO GUTIÉRREZ
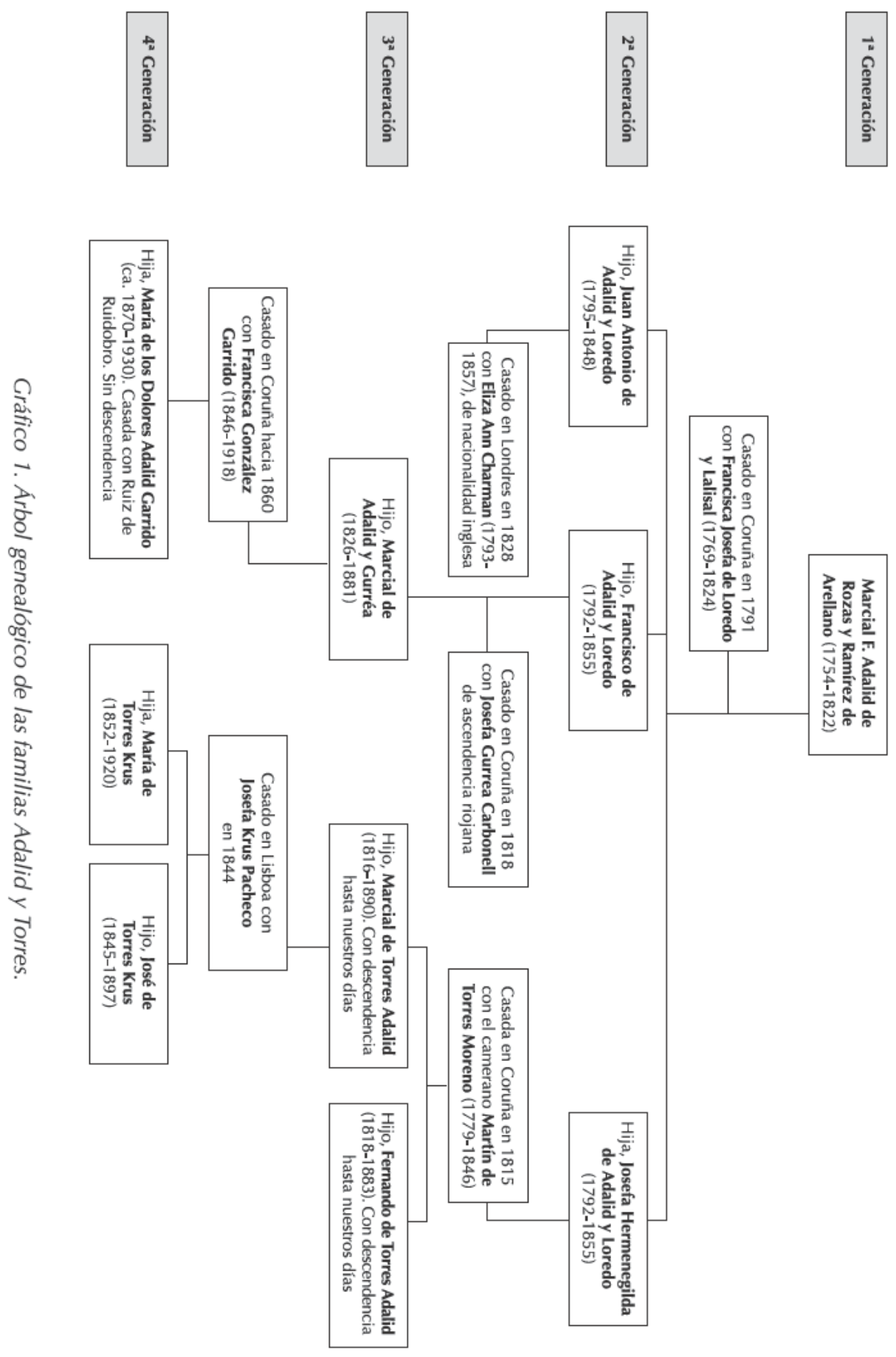
de música de cámara vocal -ópera o arreglos de ópera para piano y voz-con un 16\% de ocupación. El 9\% restante es de música orquestal -conciertos para violín, oberturas y sinfonías-. La otra gran serie de partituras del fondo Adalid pertenece al afamado pianista y compositor Marcial del Adalid y Gurréa (A Coruña, 1826; A Coruña, 1881), hijo de Francisco del Adalid y por lo tanto tercera generación del clan. Las ediciones de las obras responden a los años que giran en torno a 1840 y 1881 . Predomina la música para piano -parte de ella composiciones del propio Marcial del Adalid-seguida por música seria instrumental de cámara con piano, música vocal y en último lugar por música orquestal7. Dado que la mayoría de obras de esta serie fueron compradas en la segunda mitad del siglo XIX y puesto que por el momento no se ha hecho un inventario o catálogo de la serie de Marcial -a excepción de sus composiciones-, no la tendremos en cuenta en este estudio ${ }^{8}$.

El fondo de partituras de la familia Torres se encuentra en la actualidad en un archivo privado perteneciente a descendientes directos del clan ${ }^{9}$. Al igual que el fondo de sus primos los Adalid, encontramos diferentes series de colecciones de partituras adquiridas y organizadas en volúmenes encuadernados por miembros de varias generaciones del clan Torres. La serie principal pertenece al también pianista y compositor Marcial de Torres Adalid (A Coruña, 1816; A Coruña, 1890), miembro de la tercera generación de los Adalid y de la segunda generación de los Torres en A Coruña -véase Gráfico $1{ }^{10}$. La colección de Marcial de Torres recopila obras que fueron editadas entre ca.1820 y ca.1890, la gran mayoría por editoriales extranjeras. Tras la localización de nuevos documentos y tomando como referencia el inventario realizado por la estudiosa Margarita Soto-Viso, hemos podido contabilizar un total de cuatrocientos ochenta y siete números de opus que podrían albergar en torno al millar de piezas ${ }^{11}$. Prevalece sobre el resto de secciones musicales la dedicada a la música para pia-

7. También hemos incluido en esta serie la música que perteneció a María del Adalid, hija de Marcial del Adalid.

8. Soto Viso, Margarita, "Catálogo provisional de Marcial del Adalid, estudio sobre la significación de su obra pianística", en Revista de Musicología, II, 1979, pp. 327-342. Íd. "Adalid Gurrea, Marcial del", en Diccionario de la Música Española e Hispanoamericana, Emilio Casares (dir.), Madrid, SGAE, 1999, vol. 1, pp. 60-70. En la actualidad estamos en pleno proceso de catalogación de esta segunda gran serie musical.

9. El archivo actual se Ilama Archivo Pazo de Vila Suso. Fondo Torres Adalid (APV Torres Adalid).

10. Martín de Torres Moreno (Torrecilla de Cameros, 1779; A Coruña, 1846), padre de Marcial y Fernando de Torres Adalid, es el patriarca de la saga Torres en A Coruña. También oriundo de Tierra de Cameros (La Rioja) llegó a A Coruña a principios del siglo XIX. Se casó con Josefa del Adalid y Loredo (A Coruña, 1794; A Coruña, 1818), hija del patriarca camerano de los Adalid y hermana de Juan Antonio y Francisco del Adalid.

11. Previamente a este estudio, la estudiosa Margarita Soto Viso hizo un inventario de las obras de la colección Torres pero, desafortunadamente no efectuó un cómputo de las mismas y quedó 
no solo, órgano u harmonium solista con un $51 \%$ de números de opus -parte de ella de composiciones de Marcial de Torres y de Marcial del Adalid- seguida por la sección de música de cámara formada por tríos, cuartetos y quintetos con piano, órgano u harmonium y por piezas de piano a cuatro manos con un $38 \%{ }^{12}$. El último lugar, con un $11 \%$ de ocupación, lo forman las obras de música para guitarra y las piezas vocales, pertenecientes respectivamente al hermano y a la hija de Marcial de Torres, Fernando de Torres Adalid (A Coruña, 1818; A Coruña, 1883) y María de Torres Krus (Lisboa, 1852; San Sebastián, 1920).

En este estudio nos centraremos en las particularidades del fondo musical Adalid y en las de sus coleccionistas, pero nos apoyaremos principalmente en la rica documentación privada de la rama de los Torres, dado que apenas contamos con fuentes que documenten la vida privada y doméstica de la rama Adalid-correspondencia, libros de comercio, facturas, etc. La falta grave de fuentes privadas de esta saga familiar se debe principalmente a dos motivos. El primero proviene de omitir en los testamentos de los miembros de estas familias, los desgloses pormenorizados de los bienes heredados, práctica que se hizo desde las segundas generaciones hasta las cuartas -a excepción de la rama Adalid a raíz de su unión con los Torres-. Las herencias eran únicas y universales porque algunos de sus integrantes o no tuvieron descendencia -caso de Juan Antonio del Adalid y María del Adalid y Garrido- o tuvieron un único hijo -caso de Francisco del Adalid y de Marcial del Adalid y Gurréa- ${ }^{13}$. El segundo motivo,

pendiente la catalogación. Véase Soto Viso, Margarita, "Marcial de Torres Adalid (1816-1890). Estudio biográfico y edición de su trío con piano", en Anuario Musical, XLV (1990), pp. 189-234. Íd. "Marcial de Torres Adalid. La recepción del harmonium en el salón lisboeta de los Krus", en Boletim da Associaçao Portuguesa de Educaçao Musical (1993), pp. 35-37. Al no existir una catalogación pormenorizada de las obras no hemos podido contabilizar el número exacto de ellas. Para el recuento de piezas hemos tenido en cuenta los números de opus -entiéndase que un opus puede tener varias piezas musicales- según el inventario de Margarita Soto-Viso. Pero también hemos tenido en cuenta otras obras que en la actualidad no están en el fondo pero que fueron adquiridas coetáneamente a las otras piezas. Sabemos estos datos a raíz de la localización de nuevas fuentes que documentan su compra, como el cuaderno personal de apuntes de Marcial de Torres Adalid o las facturas de tiendas de música donde los Torres compraron partituras.

12. Aunque no hemos hecho un estudio sistemático de las fechas de edición de las partituras, creemos que la mayoría de ellas fueron compradas coherentemente durante la juventud y periodo de formación musical de Marcial de Torres. Es decir, desde aproximadamente 1820 hasta el año de 1846, coincidiendo este último con el año en que murió su padre y tuvo que tomar las riendas de la empresa familiar como hijo primogénito. Desafortunadamente muchas de las obras camerísticas están incompletas al faltarles algunos volúmenes de las distintas partes instrumentales.

Marcial continuó comprando partituras y desarrollando su faceta de músico amateur hasta el día de su muerte. Hacia 1850 comenzó su etapa de mayor creación musical con la producción de varias composiciones para harmonium.

13. Juan Antonio dejó como heredero universal a su hermano Francisco y una pensión vitalicia a su mujer Eliza Ann Charman. Francisco del Adalid legó todo a su único hijo. Consúltense en Archivo Notarial de A Coruña (ANC), protocolo 7017, (año de 1848), fols. $75-76$ y protocolo 7021 (año de 1852), fols. 264-266. 
imbricado directamente con el primero, reside en el hecho de que el último integrante de la rama Adalid en A Coruña, María del Adalid y Garrido (A Coruña, 18?; A Coruña, 1930), carente de hermanos e hijos, donó todos los bienes familiares a la orden Salesiana de A Coruña, a excepción de la biblioteca musical y de una biblioteca de libros ${ }^{14}$. Entre otros bienes legó el Pazo de Lóngora, dónde presuntamente estaban todos los documentos y enseres privados de la familia. Entre estos posiblemente estuviesen los instrumentos musicales familiares, como el piano o pianos que María habría heredado de su padre Marcial del Adalid, o incluso el arpa que tenía ella en propiedad ${ }^{15}$.

Partiendo de la discusión sobre si puede considerarse música un fondo de partituras como el de Adalid, caracterizado por no contener apenas marcas de ejecución sobre las obras y por ser la música instrumental de cámara seria su repertorio más representativo, demostraremos que para discutir la sonoridad o insonoridad de sus partituras no podemos depender únicamente de evidencias visibles, física y figuradamente hablando, sino que debemos buscar aquellas que se ocultan y que en un primer momento resultan incluso invisibles. Para ello, nos hemos servido de fundamentos teóricos procedentes de la historia cultural de la música y de la historia social de la cultura escrita, utilizando principalmente recientes teorías musicológicas que giran en torno al objeto de estudio y que han sido aplicadas en diferentes contextos históricos y geográficos ${ }^{16}$. Los últimos estu-

14. Se desconoce por completo qué es lo que hicieron los Salesianos con los bienes de los Adalid pero desaparecieron todos a excepción de unos pocos documentos que el historiador Adolfo Anta Seoane depositó en la BRAG el 31 de agosto de 1956, fruto de sus visitas al Pazo de Lóngora en los primeros años de ocupación salesiana del palacio (BRAG, Archivo). A raíz de este acto se conserva el acta de partición de bienes de la herencia que dejaron a hijos y nietos Marcial Francisco del Adalid y Ramírez de Arellano y su mujer Francisca de Loredo y Lalisal.

15. Anta Seoane afirma que Francisco era dueño de un piano: "El 8 de julio de 1842 se celebró en el Teatro Nuevo de La Coruña, que acababa de edificarse, un concierto a beneficio del Hospital de Caridad, en el que se utilizó el piano de D. Francisco del Adalid, padre de nuestro músico. Y en el Pazo de Lóngora existían dos o más, lo que da idea del amor al arte que ya iba germinando en los ambientes familiares por aquella época..." (Anta Seoane, Adolfo, "Marcial del Adalid falleció en Liáns y su cuerpo recibió sepultura en el cementerio de La Coruña", en Abrente, vol. 8, [1976], pp. 83-93). Aún así, los datos aportados por Anta Seoane hay que tomarlos con mucha prudencia ya que no suele citar sus fuentes y hemos encontrado varias contradicciones en algunos datos de sus escritos. Por otro lado, el historiador Carlos Martínez-Barbeito ("Pequeña historia de un pazo coruñés", publicación desconocida), sólo aporta información sobre el piano de Marcial, refiriéndose a él como piano de cola Pleyel traído de París sin especificar fechas. En esta publicación se incluye una fotografía de la hija de Marcial, María, retratada con un arpa.

16. Bashford, Christina, "Historiography and Invisible Musics: Domestic Chamber Music in Nineteenth-Century Britain", en Journal of the American Musicological Society, LXIII, 2 (verano 2010), pp. 291-360; Etzion, Judith. "Música Sabia'"; Cascudo, Teresa y Aguilar-Rancel, Miguel Ángel, "Género, musicología histórica y el elefante en la habitación", en Estudos de gênero, corpo e música: abordagens metodológicas. Isabel Porto Nogueira y Susan Campos Fonseca (eds.), Série Pesquisa em Música no Brasil, Goiania, ANPPOM, en prensa; Lepper, 
dios de William Weber sobre el gusto musical de la élite social de la Restauración europea y los de Christina Bashford sobre la utilización de la música de cámara en Reino Unido en contextos domésticos del siglo XIX, han sido los más recurrentes. Weber conecta el gusto musical de la élite social minoritaria con el movimiento idealista. Los seguidores de este movimiento, defendían una cultura musical elevada basada en el gusto por la "música clásica" y en la reacción contra la creciente comercialización de la ópera y la vida del concierto virtuoso ${ }^{17}$. Bashford se marcó como objetivo establecer qué tipo de tradición de música de cámara doméstica y seria existió en Reino Unido durante el siglo XIX. Cuestionó las teorías tradicionales de la historiográfica británica que mantenían que la música de cámara seria fue insignificante ${ }^{18}$. Basó el problema de la aparente escasez de consumo de música de cámara en la invisibilidad que rodeaba la práctica de esta música en la esfera doméstica. Según su ensayo teórico, la invisibilidad se debía a la utilización que habían hecho los estudiosos de fuentes documentales no adecuadas, pero también a problemas culturales arraigados en la práctica privada de la música de cámara de ejecutantes varones de la élite social ${ }^{19}$.

\section{El porqué de una biblioteca musical exclusiva: educación de élite para la élite}

Los Adalid y los Torres sobresalieron como miembros principales de la élite social incluso más allá de las fronteras de A Coruña, su ciudad de residencia ${ }^{20}$.

Richard, Music and image. Domesticity, ideology and socio-cultural formation in eighteenthcentury England, Cambridge, Cambridge University Press, 1998; Martínez, Jesús A., "Las transformaciones editoriales y la circulación de libros", en Orígenes culturales de la sociedad liberal, (España siglo XIX), Jesús A. Martínez (ed.), Madrid, Biblioteca Nueva, Editorial Complutense y Casa Velázquez, 2003, pp. 19-36; Ib., "La cultura nobiliaria: sociabilidad cultural y lecturas de la nobleza en la España del siglo XIX", en Historia Contemporánea, no 13-14 (1996) pp. 267-280; McVeigh, Simon. "'An Audience for High-Class Music'. Concert Promoters and Enterpreneurs in Late-Nineteeth-Century London", en The Musician as Enterpreneur, 1700-1914. Managers, Charlatans and Idealists. William Weber (ed.). Indiana University Press, 2004, pp. 162-182.

17. Según Weber el término "clásico" o "música clásica" hay que entenderlo como un concepto que antes de 1830, momento en el que se encuaderna el fondo musical Adalid, se utilizaba para designar música de varios periodos cuyo foco de atención comenzaba a girar en torno a la producción de Haydn, Mozart y Beethoven. Weber, William, The Great Transformation of Musical Taste, pp. 122-123.

18. Una labor todavía pendiente por hacer en el contexto español del siglo XIX.

19. Este ensayo utilizamos los términos domestic music making y musicking de acuerdo con el uso que Bashford hace de ellos. Domestic music making se utiliza para expresar la interpretación de la música de cámara en privado evitando emplear el término domestic performance reservado para eventos intencionadamente con audiencia. Musicking significa tomar parte en una performance musical, ya sea tocando, bailando, escuchando, ensayando o practicando, o aportando material para la performance. Bashford, Christina, "Historiography and Invisible Musics", pp. 303-304.

20. Incluso es probable que estas familias fuesen de las más ricas de la alta burguesía comercial española pero por el momento no contamos con los datos suficientes para corroborarlo. El 
Reunieron una inmensa fortuna gracias a sus negocios de comercio al por mayor con plazas españolas, europeas y americanas ${ }^{21}$. Trabajaron a través de sus firmas comerciales que respondían a los nombres de "Marcial Francisco de Adalid e Hijos" y "Martín de Torres Moreno", sociedades dirigidas respectivamente por los patriarcas de cada una de las sagas hasta que se producía su fallecimiento y pasaba el cargo a hijos, hermanos y nietos.

Blindaron y potenciaron sus negocios sirviéndose de diferentes estrategias políticas, sociales, ideológicas y culturales. Por un lado buscaron ocupar los puestos de poder más relevantes de la ciudad como ciertas concejalías del ayuntamiento coruñés, ejerciendo como diplomáticos de consulados de ciudades europeas y americanas, siendo militares destacados u ocupando cargos de cónsules y/o priores en el Real Consulado de Comercio de A Coruña, entre otros puestos ${ }^{22}$. Por otro lado practicaron una política de clanes familiares de clase, entendida esta última y de acuerdo con los estudios del historiador Joaquín Giró Miranda, como la unión de clanes del mismo grupo social ${ }^{23}$. Además, ambas familias compartieron perfiles ideológicos similares con una firme

prestigio internacional de las marcas comerciales de los Torres y los Adalid se puede constatar, entre otros ejemplos, a través de la aparición de sus nombres dentro del grupo de Négociants de A Coruña en la revista de acreditada reputación para el comercial de la época, Almanach du commerce de Paris, des départements de la France, et des principales Villes du Monde, 1820, pp. 1113.

21. Tenían barcos de entera propiedad o en sociedad con otros comerciantes. Mantuvieron negocios frecuentes con otras sociedades comerciales de A Coruña, de otras ciudades españolas como Bayona, Madrid, Cartagena, Sabadel, etc., europeas fundamentalmente con París y Londres y americanas como La Habana, Montevideo, Buenos Aires y Nueva Orleáns. En todas ellas disfrutaban de prestigio reconocido. Estas relaciones comerciales se realizaban a través de correspondencia mercantil o mediante agentes que defendían sus intereses y, en algún caso, mantenían sucursales de sus propias firmas.

22. Los patriarcas de ambas sagas ejercieron en varias ocasiones de cónsules y priores del Real Consulado de Comercio de A Coruña (véase Sánchez Rodríguez de Castro, M. C., El Real Consulado de La Coruña: Impulsor de la llustración (1785-1833), Sada, Ediciós do Castro, 1992). Por otro lado, según documentación hallada en el APV Torres Adalid, Martín Torres Moreno ejerció de Vicecónsul de México en A Coruña entre 1838 y 1846 y su hijo, Marcial de Torres, ejerció de Vicecónsul de la ciudad libre y hanseática de Hamburgo en A Coruña entre 1839 у са. 1855.

23. "La estrategia del pater familias es desarrollar una política matrimonial que creen uniones recíprocas y del mismo status. Se evita la dispersión del poder y se acrecienta (...)" en Giró Miranda, Joaquín, "Apuntes sobre un proyecto de investigación: adaptación y cambio. La industria pañera hacia el capitalismo industrial, 1750-1850", en Brocar, 20 (1996), p. 270. Es importante subrayar la práctica endogámica que se ejercía en la época en A Coruña entre familias con una misma procedencia y estatus social similar, en estos casos coincidentes con un origen camerano y con la adscripción al grupo social oligárquico de la burguesía comercial. Los casos más evidentes de este tipo de políticas matrimoniales en la familia Adalid son los protagonizados por los casamientos de Francisco del Adalid con Josefa Gurréa Carbonel, hija de comerciante riojano, y de Josefa del Adalid con Martín de Torres Moreno -consúltese el Gráfico 1-. 
adscripción al liberalismo ${ }^{24}$. Pero fueron sus valores culturales los que ocuparon un puesto imprescindible en esta escala de estrategias porque, no sólo les sirvieron para mejorar sus negocios, sino también les ayudaron a optimizar su estatus social, su prestigio y su poder.

De acuerdo con el historiador Jesús A. Martínez, entre el siglo XVIII y primera mitad del siglo XIX, el capital simbólico de la nobleza se reprodujo, fusionó y universalizó, hasta que finalmente se produjo la apropiación mutua de valores entre nobleza y burguesías que dio lugar al basamento de la élite del poder del sistema liberal durante la segunda mitad del siglo XIX ${ }^{25}$. Muchos de los valores culturales adquiridos por las familias de la alta burguesía, provenían de la imitación de hábitos y costumbres aristocráticas, fundamentalmente de aquellas que actuaban como referentes simbólicos externos de su estatus social y que podían exhibir socialmente. Consecuentemente, tanto los Adalid como los Torres solicitaron títulos nobiliarios, invirtieron gran parte de la fortuna familiar en una exquisita formación cultural e imitaron los espacios de sociabilidad cultural de la nobleza ${ }^{26}$. La instrucción educativa fue muy completa, sobre todo en las segundas y terceras generaciones, sobresaliendo por encima de la media de las familias principales de A Coruña. También compraron palacios en los alrededores de la ciudad, como el de Lóngora de los Adalid y el de Torres de Santa Cruz de los Torres, ambos localizados en la parroquia de Liáns (Oleiros, A Coruña) ${ }^{27}$. Por supuesto, el mobiliario, los cuadros, las partituras y la biblioteca eran elementos imprescindibles dentro de todo ese paisaje doméstico emblemático asociado a la cultura. Sus ricas bibliotecas albergaban libros escritos en diferentes lenguas -inglés y francés- que dominaban a la perfección ${ }^{28}$. La biblioteca más sobresa-

24. E incluso, en el caso de los Adalid, hay relación con grupos masones. Véase Alonso Álvarez, Luis, Comercio colonial y crisis del Antiguo Régimen en Galicia (1778-1818), La Coruña, Xunta de Galicia, 1986; Barreiro Fernández, Xosé Ramón, O liberalismo coruñés. A segunda xeración, A Coruña, Real Academia Galega, 1997; Mariño Bobillo, Mª Consuelo, La Coruña bajo el reinado de Fernando VII. La burguesía comercial, La Coruña, Arenal publicaciones, 2009; Valín Fernández, A. J. V., La masonería y La Coruña. Introducción a la historia de la masonería gallega. Vigo, Edicións Xerais de Galicia, 1984.

25. Martínez, Jesús A., "Las transformaciones editoriales".

26. Consúltese Basanta de la Riva, Alfredo, Catálogo genealógico de Vizcainías (Adición a la obra "Nobleza Vizcaína"), dos tomos, Madrid, Tipografía de Archivos, 1934; Martínez-Barbeito, Carlos, "Informaciones genealógicas del Archivo Municipal de La Coruña", en Hidalguía, Revista de genealogía, nobleza y armas, no 35, (1959), pp. 519-520. Íd. no 36, (1959), pp.134135 y 624-640; Rubio de Tejada y Fernández, Tomás, El Solar de Tejada. Asientos y Elecciones 1569 a 2008, Logroño (La Rioja), 2008.

27. Entre otras posesiones en la ciudad y alrededores, eran dueños de numerosos inmuebles situados en la parte de moda de A Coruña de la primera mitad del siglo XIX como en la zona de Los Cantones.

28. Como ejemplo del dominio del inglés se conserva en el ANC, protocolo 8063, (año 1816) fols.196-199, un documento de 1816 en el que consta la traducción hecha Francisco del Adalid del inglés al español, de un documento notarial. 
liente de estas dos familias y posiblemente de A Coruña era la de los Torres, contenedora de más de cuatrocientos cincuenta volúmenes. Conservaba entre sus fondos valiosos incunables y sirvió como fuente fundamental para las investigaciones de Enrique de Vedía -historiador y diplomático coetáneo de Martín de Torres Moreno- en la escritura de su libro sobre la historia de A Coruña ${ }^{29}$.

La serie de partituras encuadernadas entre 1826 y 1827 de la biblioteca musical Adalid, funcionaba también como importante referente simbólico externo del estatus social de la familia. Su contenido, música de cámara instrumental seria, respondía a la imitación de las prácticas culturales de los miembros de la élite o clase alta de las plazas foráneas con las que tenían mayores relaciones comerciales, como era el caso de Francia e Inglaterra ${ }^{30}$. Una música de minorías y poco usual entre las clases altas españolas de la Restauración ${ }^{31}$.

29. Hay que tener en cuenta que el número de libros de la librería de los Adalid ha sido tomado de un documento notarial de 1822, por lo que desconocemos la cantidad de libros que continuaron comprando sus hijos posteriormente a esta fecha, como así hicieron con la compra de partituras. Contamos con ciertos indicios de su afición bibliófila al encontrar a los miembros de la segunda generación como suscriptores de algunos libros de edición española la suscripción a una colección de novelas de la imprenta valenciana de "Estevan" editadas entre 1818 y 1819 . En el caso de los Torres conocemos los datos de la biblioteca a raíz de una tasación e inventario que hicieron los herederos en 1899 en el que se aludía a los incunables -consúltese el Archivo Histórico del Reino de Galicia (AHRG), Sección Familias, caja 89/57, referencia tomada de Parrilla García, Carmen, "De copias decimonónicas de cancionero", en Nunca fue pena mayor: (estudios de literatura española en homenaje a Brian Dutton), Victoriano Roncero López, Ana Menéndez Collera (eds.), Cuenca, Ediciones de la Universidad de Castilla-La Mancha, 1996, pp. 517-530-. Por otro lado, gracias al cuaderno de notas de Marcial de Torres conocemos algunos de los numerosos libros que el propio Marcial compró para la biblioteca Torres en sus viajes a Lisboa.

30. Tenían especiales relaciones comerciales con París y Londres, aunque más intensamente con Londres. Su dinero se guardaba en prestigiosos bancos de estas ciudades, entidades que al mismo tiempo actuaban como casas comerciales en muchos de los casos. El dinero estaba listo para ser usado en cualquier negocio o transacción que la casa familiar necesitase realizar entre lo que podríamos incluir la compra de partituras. Para más información sobre las relaciones entre comercio y música que establecieron ambas sagas familiares con estas ciudades consúltense Queipo Gutiérrez, Carolina, "Boccherini, Haydn, Beethoven in Restoration Spain" y Íd. "El fondo musical Adalid y las prácticas musicales domésticas".

31. Hasta la fecha no se conocen otros indicios tan contundentes sobre el consumo de música de cámara seria entre la alta burguesía española, pero no significa que no existan o que no existieran. En el resto de Europa, la práctica musical de este tipo de repertorio estaba estrechamente relacionada con la riqueza y tiempo libre y por lo tanto, con un grupo social que se lo pudiera permitir. En este sentido es apropiado recordar que el historiador William Weber -The Great Transformation of Musical Taste-, al igual que Jesús A. Martínez plantea en cuestiones de historia de la cultura escrita del siglo XIX -véase el párrafo del texto relacionado con la nota 25-, también defiende la existencia internacional decimonónica de una élite social o clase alta, por él Ilamada como "common upper class". Este grupo de minorías estaba formado por parte de la alta burguesía y de la clase aristocrática. La coincidencia de sus gustos musicales comunes hizo que lideraran lo que Weber Ilamó como Musical Idealism. 


\section{Evidencia visible}

Como hemos demostrado en anteriores estudios, existen numerosas evidencias que presentan a Juan Antonio del Adalid como el principal comprador de la serie musical durante su estancia en Londres. Recientemente hemos podido confirmar que la fecha de su llegada a la capital británica fue antes de 1826. La nueva fecha lo sitúa viviendo en Londres en abril de 1825 en la zona residencial de moda del West End ${ }^{32}$. Hasta el momento de su partida, finales de 1828 y tras su boda londinense, tejió presuntamente redes comerciales y amistosas con los miembros de la élite social londinense ${ }^{33}$. Sin embargo, parece que fue su hermano Francisco del Adalid quién muy posiblemente se encargó de la encuadernación de la colección musical y de plasmar la gran mayoría de las marcas manuscritas que hemos encontrado en dicho fondo ${ }^{34}$.

Las anotaciones manuscritas más numerosas las constituyen las numeraciones de prácticamente todas las portadas de las partituras y de muchas de las partichelas de las diferentes partes instrumentales. También están las copias manuales de los índices de obras que aparecen en la segunda hoja de algunos de los volúmenes ${ }^{35}$. La marca menos usual aparece en algunas portadas de las partituras y es la que tiene el apellido de aquella persona que presumiblemente se encargaba de tocar una parte instrumental o vocal de una obra. Este es el caso de las piezas L'Italiana in Algeri y La Cenerentola de Rossini, adaptadas

32. "Del Adalid, John Antonio, Esq. 37. Tonbridge place, Euston-square", en Boyle's Fashionable Court and Country Guide and Town Visiting Directory, corrected for April, 1825. Containing an alphabetical arrangement of the names and places of abode, in town and country, of all the ladies and gentlemen of fashion, with the family names of the nobility, to which are added the inns of court, \&c. with a list of coffee-houses, \&c. London, Eliza Boyle \& Son, 1825. Esta guía de Eliza Boyle era muy recomendada en el Londres del XIX para encontrar los nombres y residencias de los miembros de la nobleza, alta burguesía y personas notables de la zona del West End -véase John Wallis. London: being a complete guide to the British capital: containing a full and accurate account of its buildings, commerce, curiosities ... including a sketch of the surrounding country, with full directions to strangers on their first arrival. London, Sherwood, Neely, and Jones, 1814, p. 12-.

33. Prueba de ello son las relaciones financieras que tejió con las casas de banca y comercio de Frederick Huth and Cie y de Baring and Brothers -para más información consúltese Queipo Gutiérrez, Carolina, "El fondo musical Adalid y las prácticas musicales domésticas"-. En junio de 1828 Juan Antonio contrajo matrimonio en Londres con Eliza Ann Charman, pianista inglesa amateur -en London Metropolitan Archives, Church of England Parish Registers, 1754-1921, All Souls, Langham Place, Parish of ST. Mary-Le-Bone, in the County of Middlesex (Borough of Westminster), Register of marriages, P89/ALS, Item 047.

34. Entre las marcas que no pertenecen a la edición impresa de las partituras y que no se corresponden con la grafía de Francisco, están las rúbricas de los editores musicales sobre las portadas.

35. Los índices están en los libros de las signaturas 125 a 127 y en la 174. 

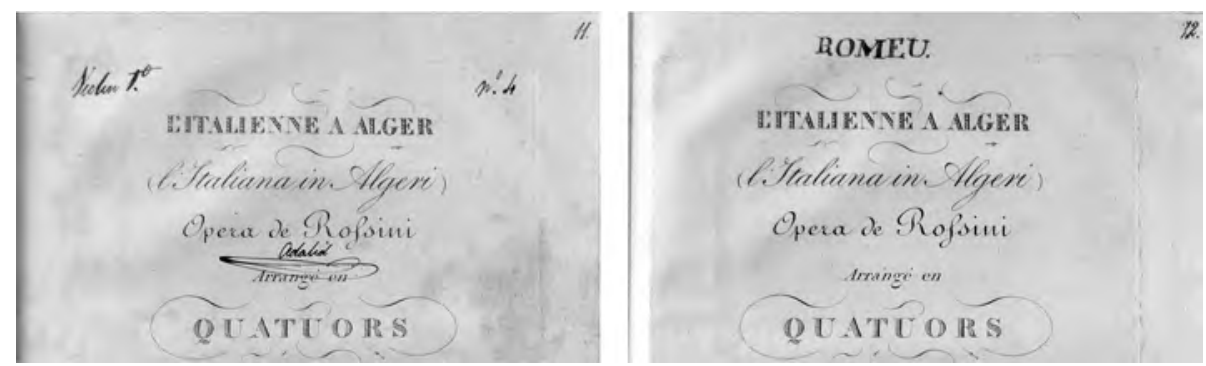

Imagen 1. Juego 2, cuartetos, signaturas 005 a 008. Parte superior de las portadas localizadas en la parte del violín primero, signatura 005.

para cuarteto de cuerda ${ }^{36}$. En las portadas de los primeros violines constan los nombres de Adalid y Romeu en la primera y segunda parte de L'Italiana, respectivamente. En La Cenerentola sólo aparece escrito Romeu en la portada de la primera parte (véase Imagen 1). En el caso de los Adalid la firma coincide con la de Francisco del Adalid mientras que la rúbrica de Romeu pertenece a Francisco Romeu, uno de los comerciantes con los que los Adalid habían entablado más fuertes relaciones comerciales y amistosas y del que consta, según otras fuentes, era asiduo a los espectáculos organizados en la ciudad ${ }^{37}$.

Ciertas marcas manuscritas de la portada de la parte primera de L'Italiana se asemejan a las marcas que albergan algunas portadas de obras de Beethoven albergadas en un juego de volúmenes diferente. Dichas obras de Rossini y Beethoven contienen en el centro de las portadas de la parte del violín, el apellido Adalid, junto con la palabra Violin $1^{\circ}$-o Viola en el caso de la parte de este instrumento de las obras de Beethoven- situada en el margen superior izquierdo, y un número en el margen superior derecho. En el caso de L'Italiana, el número corresponde al $4^{\circ}$, mientras que en el caso de las obras de Beethoven, los cuarte-

36. Las partituras se localizan en el juego 2 cuartetos y bajo las signaturas 005 al 008 . La dirección de la tienda de Gambaro en las partituras y el número de plancha sitúan el momento de edición de estas obras en París hacia el año de 1818.

Las dataciones de las partituras de todo este trabajo de investigación están basadas en los estudios sobre edición musical de Devriès, Anik-Lesure, François, Dictionnaire des éditeurs de musique français, 2 vols., Genève, Minkoff, 1979-1988 (Archives de l'edition musicale francaise, 4).

37. Comerciante al por mayor disponía de varios barcos y gestionaba los intereses y ciertas empresas de otros comerciantes como Pedro de Llano, con los que los Adalid y los Torres tenían también negocios. En el año de 1820, Romeu destacó como miembro de la corporación constitucional del Ayuntamiento de A Coruña desempeñando el cargo de Comisario de policía que entre otras misiones, tenía vigilar el contenido y el orden de todos los espectáculos -en Mariño Bobillo, Ma Consuelo, La Coruña bajo el reinado de Fernando VII, pp. 539-540-. Es decir, se puede deducir que era un hombre relativamente culto, que conocía el funcionamiento de los espectáculos y que muy posiblemente tocase el violín como intérprete amateur. 

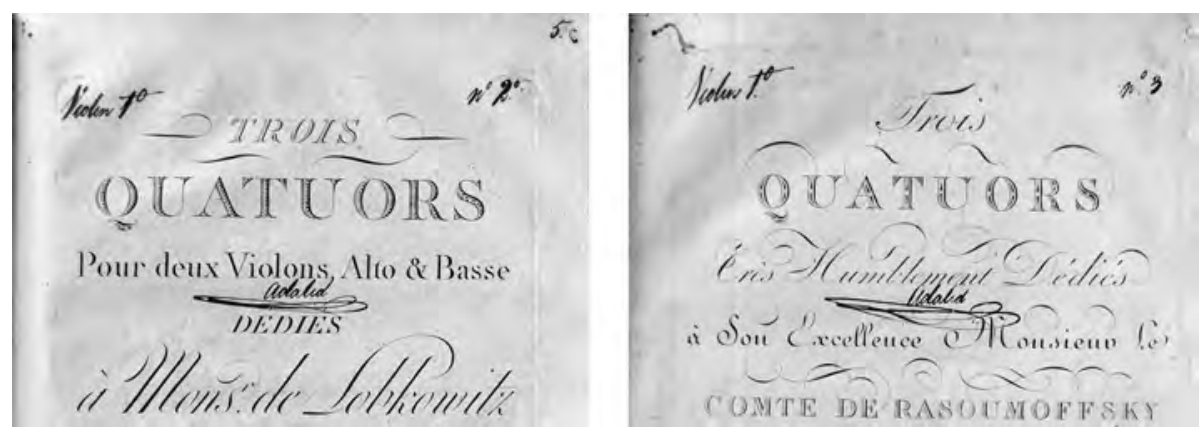

Imagen 2. Juego 4, cuartetos y quintetos, signaturas 013 a 017. Parte superior de las portadas localizadas en la parte del violín primero, signatura 013.

tos de los opus 2, 18, y 59 y los quintetos de los opus 4 y 5 se corresponden con los números $1^{\circ}, 2^{\circ}, 3^{\circ}, 5^{\circ}$ y $6^{\circ}$ respectivamente ${ }^{38}$. La numeración no coincide con la recogida en la etiqueta de la tapa del volumen de la parte del violín, por lo que las obras pueden o haber sido tocadas antes de encuadernarse, siguiendo la anterior numeración, o una vez encuadernadas pudieron haber sido seleccionadas y numeradas de acuerdo con algún fin práctico (véase Imagen 2). Un caso parecido de este tipo de seriación vuelve a darse en los quintetos para violonchelo de Bernard Romberg (1767-1841) y de J. Muntz Berger (1769-1844). En todas las portadas consta el escrito $5^{\circ}$ de V $[$ iollon]chelo -quintetos de violonchelo-. El quinteto de Romberg es el $1^{\circ}$ y le siguen otros cuatro quintetos de Muntz Berger con la numeración del $2^{\circ}$ al $5^{\circ}$. En esta ocasión la numeración coincide con la dispuesta en la etiqueta de la portada de la tapa del volumen de la parte del violonchelo ${ }^{39}$.

38. Las partituras se localizan en el juego 4 de cuartetos y quintetos y bajo las signaturas 013 a 017 . Fueron editadas por las firmas editoriales parisinas Sieber, Omont y Imbault y redistribuidos por Meysenberg entre 1820 y 1822. Los títulos completos de las obras son: Trois Quatuors très Humblement dédiés à son Excellence Monsieur le Comte de Rasumoffsky Conseiller privé de sa majesté l'Empereur de Toutes les Russies, Sénateur. chevalier des Ordres de Sant André, de Saint Hexandre Newsky et Grand-Croix de celui de St Wladimir de la première Classe op.59. Trois Quatuors por Deux violons, alto et basse, Dédiés à Mons de Lobkowitz . Op.18 $\left(1^{\circ}\right.$ livre quatours). Trois Quatuors por Deux violons, alto et basse, Dédiés à Mons de Lobkowitz. Op.18 (2 $2^{\circ}$ livre quatours). Trois Quatuors concertants pour Deux violons, alto et basse. $4^{\circ}$ livre quatours -según nuestras pesquisas se trata del opus 2 normalmente titulado como Trois / Quatuors / Concertants / Pour deux Violons, Alto et Basse. / Composés / D’Après les Sonates de / van Beethoven / Par Ate. Blondeau / Elève de Mehul et Baillot / 4e. Livre de Quatuors Prix 9. f / Propriété de l'Editeur Enrégistrée à la Bibliote. Imple. / A Paris / Au Trophée Musical Chez Omont Editeur et Marchand de Musique Rue Neuve des Petits Champs No. 29. pres celle de Richelieu / o=8-; Grand Quintetto surnommé I'Orage pour deux violons, deux alto et violoncello, op. 5 y Grand Quintetto concertant pour deux violons, deux alto et violoncello, op. 4.

39. Es el juego número 11 que abarca las signaturas 061 para las partichelas del violonceIlo y 042 a 045 para el resto de partes instrumentales. 
En el envés de la portada de la pieza basada en fragmentos de la ópera Corradino ossia Matilde di Sabrand de Rossini, constan los nombres de los intérpretes masculinos Couto, Pérez, Auge y Pastor, correspondientes con el personaje masculino de la ópera al que interpretaban, es decir Eduardo, Corradino, Gerardo y Alibour ${ }^{40}$. En el índice o tabla temática de esta obra aparecen señalados con una cruz todos los números musicales acompañados de la especificación manuscrita de los personajes correspondientes. A lo largo de la obra hay incluso traducciones manuscritas del italiano al español de algunas de las letras de varios números musicales. Nuevamente, por lo menos en los dos casos que hemos podido contrastar, los intérpretes son miembros de familias destacadas de A Coruña. El apellido Auge podría corresponder a la persona de Diego Auge, comerciante de prestigio y de ideología liberal. Unió a una de sus hijas en matrimonio con Francisco Romeu, dato con el que se cierra un círculo de familias y amistades dentro del cual la música era una práctica social de interés. Por otro lado, el apellido Pastor podría responder a la persona de José Pastor Taxonera, comerciante que formó sociedad en 1826 con los hermanos Ramón y Silvestre Dalmau bajo el nombre de "Dalmau y Pastor"41.

Otras anotaciones importantes se dispersan en diferentes obras del fondo Adalid. Una de ellas es el septeto opus 74 para piano y conjunto instrumental de cámara de J. N. Hummel (1778-1837), con las palabras sextetos y septetos/ Violín $1^{\circ}$ impresas sobre el lateral derecho de la portada de la partichela del vio$\operatorname{lín}^{42}$. Diferente ejemplo es el cuarteto opus 5 de G. Hörger ( $i$ ?) contenedor en el primer folio de la partichela del violín de la palabra Brillante ${ }^{43}$. Por último, hay ciertas anotaciones a destacar en varias de las óperas de la composición de Rossini adaptadas para piano y voz, plasmadas a lo largo de las partituras, sobre todo en los pasajes pianísticos. Estos casos son la Partition de L'Italianne a Algeri Elisabetta y La Cenerentola ${ }^{44}$.

40. Se trata del juego número 21 con la signatura 128. Es una en reducción para voz y piano que fue editada por Pacini entre 1820 y 1822.

41. Los datos sobre el matrimonio de Romeu y sobre la firma "Dalmau y Pastor" han sido tomados de Mariño Bobillo, M Consuelo, La Coruña bajo el reinado de Fernando VII, pp. 471 y 535 .

42. Está en el juego número 12 bajo las signaturas 048 a 054. Fue publicado por Artaria en 1816 y redistribuido por Ewer \& Co hacia 1825.

43. Esta pieza ocupa los volúmenes de las signaturas 143 a 146. Fue editado por Breitkopf \& Härtel hacia 1821.

44. Partition de L'Italianne a Alger -juego 31, signatura 138- publicada por Carli hacia 1820, tiene anotaciones en la página 217 en la parte del piano, lo mismo que la La Cenerentola -juego 30, signatura 137-, publicada por Pacini entre 1819 y 1827 la cual además cuenta con señales dinámicas en la parte vocal del dueto de las páginas 53, 54 y 55 y la parte del coro de la página 266. Además, en La Cenerentola y en Elisabetta -juego 27, signatura 134-, esta última publicada por Janet et Cotelle entre 1824 y 1827, se señalan mediante cruces la mayoría de los números de la tabla temática. 


\section{Música insonora o la evidencia invisible}

Una vez estudiados los documentos visibles que aportan pruebas sobre la consecución de una práctica musical en la serie de partituras, nos preguntamos por la posibilidad de que ese repertorio se proyectase en la vida pública coruñesa. Tras haber hecho un vaciado de las fuentes relacionadas con las actividades musicales públicas de la ciudad de la primera mitad del siglo XIX, podemos concluir que estas apenas reflejan en sus contenidos la ejecución de obras del fondo Ada$\mathrm{lid}^{45}$. Pero entonces, ¿ podemos dar por suficientes estas pruebas para ratificar que las partituras de la colección, carentes de marcas y que prácticamente no tuvieron proyección en la vida pública de la ciudad fueron tocadas, ensayadas o tan siquiera leídas por sus coleccionistas o por cualquier persona cercana y coetánea?; ¿hasta qué punto es significativa la aparición de señales interpretativas en las partituras para poder afirmar si una obra fue tocada?; ipor qué cuestionarnos su sonoridad en base a unas marcas si no lo hacemos cuando estudiamos una biblioteca de libros y siempre damos por sentado que se produjo una lectura individual o colectiva?; ¿no deberíamos reconsiderar el hecho de que imprimir marcas sobre las partituras realmente no formaba parte de una práctica usual en la época y menos aún cuando se trataba de música impresa, un producto ostensiblemente caro y lujoso?; ¿cuál es el criterio que los investigadores del siglo XXI deberíamos aplicar para juzgar si una colección musical como esta, adquirida por sus compradores en la primera mitad del siglo XIX y casi sin anotaciones personales en sus páginas, fue concebida para un fin interpretativo? Evidentemente las pruebas vistas hasta el momento resultan insuficientes para responder a todas estas cuestiones por lo que necesitamos apoyarnos en fundamentos teóricos novedosos y en otras fuentes documentales, a priori, menos evidentes y/o perceptibles.

Apoyándonos en los estudios de Christina Bashford y Richard Lepper sobre el contexto inglés, creemos que en la España de la primera mitad del siglo XIX y en el seno de determinados grupos de la élite social, también pudo haber convincentes razones culturales para que los intérpretes varones de música de cámara instrumental, tuvieran reticencias para el ejercicio de su ocio en públi$\mathrm{CO}^{46}$. En la sociedad inglesa decimonónica existía un significativo desdén sexista por la práctica musical de los gentleman o caballeros con cualquier grado de

45. Hemos hecho un vaciado de las fuentes musicales de la prensa publicada en A Coruña entre 1808 y 1836. También hemos buscado conexiones entre los Adalid y la actividad musical de la Real Colegiata de Santa María del Campo de A Coruña a través de su archivo -Archivo de La Colegiata de A Coruña (ACC)-. Además hemos consultado los expedientes de teatro conservados en el Archivo Histórico Municipal de A Coruña (AHMA) entre los años de 1771 hasta 1875, dedicando una mayor atención a los expedientes de la primera mitad del siglo XIX.

46. Para fundamentar su teoría, Bashford partió de los estudios aportados por Richard Lepper sobre música e imagen. Véanse Bashford, Christina, "Historiography and Invisible Musics" y Lepper, Richard, Music and image. 
seriedad o destreza. Era mucho más sencillo no hablar sobre las pasiones privadas y tampoco representarlas públicamente. Parece que en el estrato social en el que el hombre poseía riqueza, tiempo libre, interés y gusto por tocar música de cámara, preferían su cultivo en privado, oculto a la vista e incluso a veces optaban por negarlo dado que, si lo hacían público, corrían el riesgo de ser caricaturizados. Tocaban en privado, de una forma informal motivada por la satisfacción musical, intelectual y especialmente social. Por lo tanto, las marcas culturales que dejó su práctica musical fueron débiles y, consecuentemente, esto ha hecho que reciba menos atención que otros ámbitos de la práctica musical doméstica, como la música para piano o para canto y piano de salón.

La llegada hasta nuestros días de algunas imágenes de varios miembros de los clanes Torres y Adalid, confirma la teoría de la invisibilidad en lo que se refiere a la representación visual de la música en retratos de varones adultos. De acuerdo con dicha teoría, los únicos retratos familiares que incluyen representación visual de elementos musicales son los de mujeres y niños ${ }^{47}$. En ellos la música actuaba como signo reconocible de un modo de comportamiento y pensamiento aprobado ${ }^{48}$. Uno de estos retratos es el de Josefa del Adalid. Gracias a esta imagen sabemos de su afición pianística. Josefa aparece retratada de pie, delante de un piano de escuadra londinense -un William Rolfe de ca. 1810- y sujetando una partitura ${ }^{49}$. Al lado de su brazo izquierdo, sobre el piano, reposa un libro del que no alcanzamos a vislumbrar su título. Sobre el atril del piano, se percibe un volumen encuadernado similar a los conservados en las bibliotecas de ambas familias. La imagen se complementa con otros tres cuadros con los retratos de su marido Martín Torres Moreno y de sus dos hijos Marcial y Fernando de Torres Adalid $^{50}$. Desconocemos el nombre del pintor y el año de su creación pero deducimos, en base a la edad que aparentan en los retratos, que los cuadros de Josefa y Martín fueron pintados hacia 1815, al poco de casarse. En cambio los retratos de sus hijos pudieron haber sido pintados hacia 1826, con unos diez años de edad Marcial y ocho Fernando. Únicamente Marcial cuenta con elementos musicales en su imagen, nuevamente con el piano londinense que había en el retrato de su madre y con una partitura para este instrumento ${ }^{51}$. Sin embar-

47. Aunque hay que recalcar que los accesorios musicales en los retratos de niños varones también son muy escasos. Lepper, Richard, Music and image, pp. 112-119.

48. Lepper, Richard, Music and image, p. 3.

49. Novak Clinkscale, Martha, Makers of the Piano, 1700-1820, Oxford, Oxford University Press, 1993. Este piano existe a día de hoy y se conserva en Madrid, en la casa de uno de los descendientes de la familia Torres.

50. La herencia de los Torres está desperdigada en la actualidad por toda España entre los hogares de los numerosos descendientes, por lo que la recopilación del material fue un proceso costoso y complicado.

51. Llegamos a formularnos distintas hipótesis sobre qué parte de la familia se encargó de la adquisición de dicho piano. Podía haber pertenecido a Josefa del Adalid y tras su enlace con 
go, las imágenes que nos han llegado de Marcial de adulto, ocultan todo símbolo de actividad musical, quedando solo los relativos a su actividad profesional de comerciante ${ }^{52}$. Lo mismo ocurre con los retratos de su primo Marcial del Adalid, que aún habiéndose dedicado profesionalmente a la música, sus retratos más tardíos carecen de elementos musicales. Precisamente por estos factores es muy probable que, de haber existido o llegado hasta nuestros días retratos de Juan Antonio o Francisco del Adalid adultos, estos no contasen con representación de elementos musicales.

Este marco teórico ayuda a explicar la falta de marcas o anotaciones manuscritas sobre el aproximadamente $95 \%$ de las partituras de la serie musical del fondo Adalid -hay marcas sólo en diecisiete opus de la colección-. Si como todos los datos apuntan, la interpretación se daba de una forma informal, sin un público crítico, sino cercano y pequeño, la escritura de anotaciones que mejorasen la performance de las obras era irrelevante. Revisando las tipologías de las marcas que denotan, de una forma más evidente, la interpretación musical de obras del fondo, podemos concretar que en su mayoría fueron hechas para concertar los repartos de las partes instrumentales o vocales de las obras o para establecer un posible orden de ejecución. Basándonos en estos datos, podemos concluir que el tipo de instrumento musical más usual en la práctica de Francisco y Juan Antonio del Adalid debió ser de cuerda frotada, quedando en primer lugar el estudio del violín seguido por el de la viola y el violonchelo. Las rúbricas de Francisco sobre las portadas de la parte del violín y viola de obras de Beethoven y Rossini, denotan no sólo su interés por dejar constancia de la propiedad de esas piezas frente al resto de obras, como símbolo del aprecio y admiración por la composición de esos creadores, sino también por la ejecución.

\footnotetext{
Martín el instrumento pudo pasar a disposición de los Torres, algo habitual en las costumbres sociales de la época. Aunque también cabe la posibilidad de que el piano fuera una adquisición de los Torres dado que tenían relaciones comerciales con Londres, a priori, más enraizadas que los Adalid. Para más información sobre la imagen infantil de Marcial de Torres consúltese Queipo Gutiérrez, Carolina, "El fondo musical Adalid y las prácticas musicales domésticas". Por otro lado, que la biblioteca de Francisco y Juan Antonio del Adalid, fuese adquirida, organizada y encuadernada en los mismos años que la factura del retrato de Marcial, invita a pensar en que, durante la década de 1820, la música en la familia fue un elemento importante. Años en los que la representación del poder, a través de la música y en cualquiera de sus formatos, se convirtió en un acto necesario e imprescindible para ellos.

52. El retrato de su padre, Martín de Torres Moreno, sigue el mismo patrón. Tenemos poderosas razones para pensar que Martín era un gran aficionado a la música pero, sin embargo, en la representación visual de su retrato sólo hay referencias a la actividad mercantil. En varias cartas con sus hijos, es el máximo interesado en que estos se instruyan en la práctica musical. Además, en numerosas ocasiones fue el encargado de comprar algunas de las partituras recogidas a día de hoy en el fondo musical Torres, por lo que deducimos que sus conocimientos musicales fueron bastante elevados.
} 
Muchas veces, tocar la música de un admirado en la época como Beethoven era una de las aspiraciones de los aficionados. Desde luego estas obras tenían unas limitaciones técnicas claras para los intérpretes amateurs, pero curiosamente no era un hecho que condicionara su práctica. Los ejecutantes podían elegir movimientos más simples o tocar los difíciles de forma más lenta. O incluso, a veces, podían permitirse tener a un músico profesional tocando la parte del primer violín en sus sesiones, lo que les abría las puertas para hacer los cuartetos más duros del repertorio camerístico. Para el estudio del violín se sirvieron del único tratado instrumental que hay en el fondo musical. Se trata del Méthode du Violon (París, 1793) escrito por Pierre Baillot (1771-1842), Rodolphe Kreutzer (17661831) y Pierre Rode (1774-1830 ${ }^{53}$.

En la búsqueda de información que aportase más claridad, tanto sobre la inclusión de un profesional en las soirées de los Adalid, como sobre la práctica e instrucción en instrumentos de cuerda frotada que recibieron Juan Antonio y Francisco, hallamos una posible explicación en la educación militar o cívicomilitar en la que se formaron ${ }^{54}$. El caso que mejor hemos podido documentar es el de Juan Antonio. A los catorce años empezó su formación en el cuerpo de artilleros, cuerpo del ejército que contaba con una importante banda musical en A Coruña ${ }^{55}$. Durante el Trienio Liberal, Juan Antonio fue miembro activo de

53. Méthode du Violon par MM. Baillot, Rode, et Kreutzer, Membres du Conservatoire de Musique. Redigée par Baillot. Adoptée par le Conservatoire pour servir a l'Etude dans cet Etablissement. Gravée par Le Roy. A Paris. Au Magasín de Musique du Conservatoire Royal, Rúe Bergère, $n^{\circ}$ 3. Sobre la portada de este método hay unas marcas manuscritas pero al ser ilegibles las hemos obviado.

54. En coherencia con los hábitos aristocráticos de los que eran seguidores ambos clanes familiares, es lícito pensar también que Juan Antonio, Francisco y Josefa del Adalid recibieron una educación musical privada y doméstica, a través de la contratación de un profesorado asistente a domicilio. Además, contamos con documentos que confirman estas prácticas en los casos de Marcial y de Fernando de Torres Adalid -véase el párrafo del texto relacionado con la nota 60-.

55. Según documento del 13 de noviembre de 1812 del Archivo General Militar de Segovia (AGMS), Juan Antonio solicitó el ingreso de "Caballero cadete supernumerario en el Colegio Militar de Artillería". El solicitante cumplía con todos los requisitos para poder entrar en dicho colegio: contaba con la edad adecuada, su padre era el Comisario Ordenador Honorario de los Ejércitos Nacionales en la provincia de La Coruña (Marcial Francisco del Adalid y Ramírez de Arellano) y fue recomendado por Antonio López y Chávez, Mariscal de Campo del cuerpo de Artillería Nacional del Regimiento de La Coruña -AGMS, Sección $1^{a}$, Legajo A 243-.

El Real Colegio Militar de Artillería de Segovia era una institución privilegiada y elitista, de rígidas normas docentes, exigente plan de estudios y dura vida escolar. Creó un tipo de oficial nuevo, culto e ilustrado -Verdera Franco, Leoncio, "La evolución de la artillería en los siglos XVII y XVIII", en Los ingenieros militares de la monarquía hispánica en los siglos XVII y XVIII, Alicia Cámara Muñoz (coord.), Madrid, Ministerio de Defensa, 2005, pp. 113-130-. Durante los años de la Guerra (1808-1814), el colegio militar de Segovia sufrió varios traslados al sur de la Península y la formación militar de esta institución se disgregó entre diferentes centros de formación. Uno de sus principales fue el de la Isla de León en Cádiz, pero también se formaron otros como el Colegio Militar de Santiago de Compostela (20 de agosto de 1811) en el que cree- 
la Milicia Nacional coruñesa. Esta institución estaba además muy ligada a la práctica musical y, aunque actualmente no contamos con pruebas fehacientes, es muy posible que Juan Antonio fuera integrante de la banda musical miliciana, también Ilamada Sociedad Filarmónica de A Coruña, según nuestras últimas pesquisas $^{56}$. Sabemos que dicha banda actuó a lo largo de la primera mitad del siglo XIX como refuerzo fundamental de las orquestas de las diferentes compañías dramáticas que pasaron por los teatros coruñeses. Las ordenanzas milicianas explican que contrataban a músicos profesionales residentes en la ciudad para tocar en la banda y al tiempo instruir en ella. En su faceta docente, tenían la obligación de tener bajo su cargo a un discípulo ${ }^{57}$. Uno de los violinistas y violistas profesionales de A Coruña, compositor y miembro de la orquesta de la Real Colegiata de Santa María del Campo de A Coruña fue Pedro Montoro (A Coruña, 1794; Oporto, 1841) $)^{58}$. Muy probablemente pudo haber ejercido cátedra en la banda de la milicia y, por lo tanto, posible profesor de los Adalid. Aparece por primera vez referido en las fuentes consultadas como músico de violonchelo de la sección de Orquesta de la relación de los componentes de la compañía de teatro del empresario Bartolomé Alegre del año de $1809^{59}$. En este documento se diferencia claramente la sección de Orquesta, de la sección de Actores de la compañía en la que estaba incluido el Músico de Comp ${ }^{a}$-músico de la compañía- Josef Berenguer. Este dato invita a pensar que la Orquesta era una organización externa y Montoro su músico principal. El resto de músicos integrantes de esta orquesta, al igual que Montoro, posiblemente formaban

mos probable Juan Antonio realizase finalmente su instrucción -véase Xosé A. Fraga Vázquez, "Efectos en Galicia da renovación científica promovida por Sarmiento e outros ilustrados. A constitución da Academia de Gardas marinas e dos colexios prácticos", en O Padre Sarmiento e o seu tempo, Consello da Cultura Galega, Universidade de Santiago de Compostela, 1997, pp. 405-427.

56. Junto con su hermano también era miembro integrante de la Sociedad Patriótica de Coruña -Barreiro Fernández, Xosé Ramón, "La sociedad patriótica de La Coruña (1820)", La Coruña, Historia y Turismo, (2002)-. Según nuestras investigaciones, la Sociedad Patriótica compartía con la Sociedad Filarmónica miembros y local de reunión, por lo menos en el año de 1820. Véanse El Constitucional: crónica científica, literaria y política, 2 de abril de 1820 y en Biblioteca Barreiro-López Morás Diario Constitucional de La Coruña, 6 de diciembre de 1820, anuncios. En 1839, tras reaparecer la milicia en 1834, Juan Antonio ostentaba el grado de subteniente de artilleros -AMC, Expedientes de organización. Milicia Nacional, 1839, C. 4966-.

57. Rey Majado, Áurea, A Coruña y la música: El primer orfeón coruñés (1878-1882), La Coruña, Ayuntamiento de La Coruña, 2000, pp. 55-56.

58. "Pedro Montoro / Natural da Corunha (Espanha) / Tocava Rabeca e Violeta / bom Musico / homem de bem, mas muito pusilânime, e muito medroso / Finou-se aos 18 de Julho de 1841 com 47 anos. Génio Adamado, pusilânime, desconfiado e muin medroso". Esta cita facilitada por A. B. Ribas, procede del Livro de Obitos dos Professores de Musica Falecidos na Cidade do Porto, 1814/1876, lista de músicos relacionados con el teatro de São João de Oporto, http://www.geneall.net/P/forum_msg.php?id=119298\&fview=e.

59. AMC, Expedientes del Teatro, C. 17 correspondencia (1771-1875), año de 1809. 
también parte de las distintas agrupaciones instrumentales de la ciudad como la orquesta de la Colegiata, la banda de la Milicia Nacional o las bandas de los distintos cuerpos militares ${ }^{60}$. Años más tarde, el 29 de diciembre de 1820, reaparece el nombre de Montoro en un aviso del Diario Constitucional de La Coruña en el que se anunciaba de forma explícita la participación de los músicos aficionados de la Sociedad Filarmónica de la ciudad en un concierto del teatro "a beneficio del profesor de Música Don Pedro Montoro"61.

De Francisco del Adalid sabemos muy poco sobre su formación musical ${ }^{62}$. Sin embargo, su nombre aparece junto al dato más importante y quizás más revelador que hemos encontrado hasta la fecha sobre la práctica musical pública del fondo de partituras familiar. La fuente es una relación de gastos ocasionados por la celebración, en la Colegiata de la ciudad el día uno de enero de 1829, de la Misa Pontifical por la fiesta de La Circuncisión ${ }^{63}$. Esta misa fue oficiada por el obispo auxiliar del arzobispado de Santiago de Compostela, Manuel María de Sanlúcar Díaz de Bedoya (1781-1851), y pagada por los comerciantes y músicos aficionados de la ciudad. La celebración contó con la participación de la orquesta de la Colegiata a la que se sumaron músicos del cuerpo de Artillería y del cuerpo de Aragón del ejército. Entre los gastos aparece el pago "al mozo que llebó los libros de música à la casa de D. Francisco del Adalid [sic]", por lo que deducimos que se utilizaron los libros de música del fondo Adalid en un evento altamente representativo del poder del gremio de comerciantes, del que Francisco era un principal. Partiendo de los catorce instrumentos empleados en esta performance pública -tres violines, cuatro clarinetes, dos trompas, dos clarines, un fagot y una flauta-, podría haberse interpretado cualquiera de las obras integra-

60. Deducimos que era el músico principal puesto que en la lista no se especifica el nombre de otro músico, y figura además, como el integrante que más cobraba de la sección de Orquesta. Por otro lado Pedro Montoro, como muchos de los músicos profesionales residentes en Coruña, solían colaborar en todas las formaciones orquestales de la ciudad. Por fuentes localizadas en el ACC, sabemos que era músico integrante de la orquesta de la Real Colegiata de A Coruña y compositor de esta institución. Véase Velo Pensado, Ismael, Archivo de la Colegiata. Clasificación e Inventario Guía, La Coruña, 2009 y ACC, Carpeta 5.2.19.-346.5.1 y 5.2.19.346.5.2. correspondientes a los años de 1828 y 1829.

61. Biblioteca Barreiro-López Morás, Diario Constitucional de La Coruña, 29 de diciembre de 1820, anuncios: "Don Pedro Montoro, músico y compositor". Por otro lado, en un documento del AHM -AC Hacienda, Tributación, Lista general de las clases sujetas al pago de contribución [de patentes], C.3983, año 1821-, Montoro aparece bajo el epígrafe "Maestros de Música" junto con el guitarrista Pablo Segura y el pianista Constela.

62. En su posible relación de una instrucción musical dentro del ejército conocemos que en 1820 se graduó como intendente de provincia y su nombre apareció en la lista de graduados de la sección del Estado Mayor del Ejército. Estado Militar de los Ejércitos de la Monarquía Española, Imprenta Nacional, 1822, p. 45.

63. ACC, Carpeta 5.2.19.-346.5.2. La misa se celebró el uno de enero de 1829 pero las facturas fueron emitidas el siete y el nueve de enero. 
das en el juego de libros número 13 de la biblioteca, que incluye sólo obras orquestales, todas ellas carentes de marcas: conciertos para violín de Giovanni Battista Viotti (1755-1824), Joseph Mayseder (1789-1863), Charles Philippe Lafont (1781-1839) y Rodolphe Kreutzer (1766-1831); concierto para violonchelo de Victor Fenzi (i?-1827); oberturas a toda orquesta de Rossini, Beethoven, Friedrich Ludwig Aemilius Kunzen (1761-1817), Friedrich Ernst Fesca (17891826), Andreas Jakob Romberg (1767-1831), Johann Nepomuk Hummel (17781837), Ferdinando Paër (1771-1839), Adrien Boieldieu (1775-1834), Simon Mayer (1763-1845), Michele Carafa (1787-1872) y Gioseffo Catrufo (17711851); y sinfonías de Beethoven, Mozart y Joseph Küffner (1776-1856) ${ }^{64}$.

Concentrando de nuevo nuestra atención en el análisis del fondo musical podemos constatar que apenas hay partituras que contengan marcas correctivas cuyo fin fuese mejorar la práctica interpretativa como digitaciones, referencias dinámicas, señalización de adornos, corrección de alteraciones accidentales omitidas en la edición impresa, etc. Estas señales junto con la documentación inédita del APV Torres Adalid justifican la existencia de un estudio concienzudo de las obras que se destinaban, muy posiblemente, a una performance formal y abierta a un público más amplio que el habitual círculo social de los Adalid -a las que hay que añadir las obras del juego número 13 vistas anteriormente-. Estas, recordemos, son las piezas para piano y voz de Rossini de la Partition de L'Italianne a Algeri y La Cenerentola, es decir obras no incluidas dentro del repertorio camerístico principal, pero que podrían haberse integrado en una sesión de práctica musical de cámara organizado por las terceras generaciones de los Torres y de los Adalid ${ }^{65}$. No nos sorprende que las obras que cuentan con marcas de este tipo sean las pianísticas ya que los miembros de estas terceras generaciones se dedicaron casi profesionalmente al arte interpretativo y de composición de este instrumento. Si analizamos las partituras de la segunda serie musical Adalid perteneciente a Marcial del Adalid, percibimos que las únicas piezas que contienen anotaciones manuscritas de tipo interpretativo son aquellas que fueron objeto de estudio bajo la supervisión de un instructor de piano, como las obras de Ignaçe Moscheles (1794-1870). No por casualidad se repite exactamente el mismo patrón en la colección musical Torres, por lo que es preciso recordar que, Marcial de Torres primero y años después su primo Marcial del Adalid, estudiaron en Londres bajo la instrucción privada de Moscheles ${ }^{66}$.

64. El juego número 13 abarca las signaturas 055 a 079.

65. De acuerdo con Bashford los límites del género serio de la música de cámara durante una sesión práctica son borrosos ya que esta música puede confluir en una misma sesión con la práctica de otros géneros musicales. Bashford, Christina, "Historiography and Invisible Musics", p. 304.

66. Hubo un primer intento de contratar a Cipriani Potter (1792-1871), director por aquel entonces del Royal Academy of Music, pero fue fallido ya que Potter no ofrecía clases privadas. Moscheles, en cambio sí llegó a ser contratado durante una temporada y ofreció clases privadas a Marcial de Torres. APV Torres Adalid. 
Gracias a la reciente aparición de documentación privada del clan Torres hemos podido concretar que Marcial de Torres, principal creador de la colección Torres, tuvo que tocar muchas de las partituras que fue adquiriendo para su biblioteca a lo largo de los años pero que, a pesar de esa evidente dedicación práctica, estas piezas carecen de anotaciones. En 1834, los hermanos Marcial y Fernando de Torres Adalid, fueron enviados a estudiar fuera del país al abrigo siempre de familiares y amigos. Primero fueron a Burdeos y París para perfeccionar el francés y continuar la práctica musical que habían iniciado en el núcleo y biblioteca familiar de los Adalid, Fernando con la guitarra y Marcial con el piano. Su formación siguió con una estancia de aproximadamente dos años en Londres entre 1835 y ca. 183767. Según se declara en la correspondencia mantenida entre Marcial y Fernando con su padre Martín, además de aprender el idioma y enseñanzas adecuadas para su carrera comercial, ambos hermanos debían integrarse en círculos sociales londinenses de acuerdo con la educación que habían recibido. La música tenía un papel privilegiado dentro de la educación correspondiente a su status social.

Entre los documentos personales que Marcial se trajo de Londres hay una serie de cartas e invitaciones que recibió para participar en los conciertos privados, principalmente dedicados a la interpretación de música de cámara, organizados en la casa del comerciante y director del Bank of England, Timothy Abraham Curtis (1786-1857), personalidad con la que la familia Torres mantenía una fuerte relación comercial ${ }^{68}$. En más de una ocasión, T. A. Curtis instó a Marcial a llevar obras musicales de su propiedad. Ninguna de las piezas del fondo Torres, presumiblemente compradas durante la estancia de Marcial en Londres, tienen anotaciones manuscritas. Bastantes años más tarde, en la década de 1850, Marcial de Torres compró un harmonium ${ }^{69}$. Suponemos que posteriormente a esta adquisición, le acompañaron la compra de obras para este instrumento que a día de hoy se conservan en la biblioteca y que, por supuesto, dieron lugar a la prolífica producción de Marcial de piezas para harmonium $^{70}$. Jamás hubiera podido existir un producto creativo sin haberse forjado

67. El número de amigos y comerciantes con los que trataba la empresa familiar "Martín de Torres Moreno", había crecido considerablemente en estos años. Fernando y Marcial vivían, al igual que hizo su tío Juan Antonio del Adalid, en la zona del West End.

68. Timothy Abraham era hijo de Sir William Curtis (1752-1829), estimado violonchelista amateur y amigo personal del Rey Jorge IV, famoso por sus veladas musicales de música de cámara seria. Más información sobre las cartas en APV Torres Adalid.

69. Marcial de Torres Adalid deja una primera constancia de su interés por el harmonium tras copiar en su cuaderno personal de apuntes, durante su estancia en Lisboa en el año de 1854, un anuncio londinense en el que vendían harmoniums franceses.

70. Según Soto Viso, las composiciones para harmonium hechas por Marcial comenzaron en la década de 1850. Soto Viso, Margarita, "Marcial de Torres Adalid (1816-1890)". 
una práctica interpretativa previa de las obras compradas, piezas que sin embargo, carecen nuevamente de marcas.

Otro dato que relaciona práctica musical y obras del fondo Torres, proviene de la estancia de Marcial en Madrid en la década de 1860. De esta estancia se conserva una carta enviada por el violinista vasco Fermín Barech (1840-1891) al pianista amateur. En ella se deja constancia nuevamente del uso práctico de obras del fondo Torres sin dejar huellas sobre sus partichelas. La carta alude a una reunión de varios músicos -F. Barech y J. Casall- en el Café Suizo de Madrid en la que deciden escribir a Marcial para avisarle de que están libres al día siguiente para ir a su casa a tocar. En la carta no utilizan la palabra ensayo para la sesión privada con Marcial y sólo la emplean en alusión a sus deberes profesionales desarrollados al margen de esa sesión: “(...) le avisamos que desempolve todos los cuadernos de música que mañana no pensamos dejar nota sana. Los reos (el violín y el violoncello) están ya en capilla encomendando sus almas á Dios. No se olvide UD. de ellos" [sic].

El último dato que refuta la existencia de una práctica musical de las partituras de ambos fondos musicales, es la herencia cultural musical que las segundas generaciones imprimieron sobre las siguientes. Sin la escucha y práctica habitual de música de cámara en las vidas de los miembros de ambos clanes, difícilmente hubieran existido las piezas de música de cámara creadas por Marcial de Torres y por Marcial del Adalid ${ }^{71}$.

\section{Conclusión}

Las marcas manuscritas sobre las obras de compositores de éxito y coetáneos al momento de edición y compra de las partituras, denotan el interés específico que los Adalid tenían sobre estas piezas y les involucran como ejecutantes y líderes, tanto en el reparto de roles como en la organización de su práctica. Las señales, por lo tanto, son indicios útiles para apoyar la sonoridad de dichas obras. Pero dada la ingente cantidad de piezas que quedaron sin marcar y que sin embargo fueron cuidadosamente organizadas por los Adalid en volúmenes encuadernados por partes instrumentales, es lícito pensar que el fondo fue concebido con un fin eminentemente práctico. Debemos tener en cuenta que además, una biblioteca con música de cámara instrumental seria como repertorio más emblemático, debía ser exhibida como elemento asociado a la alta cultura, capaz de mejorar las relaciones sociales y de negocios que la familia había establecido con miembros destacados de la

71. De Marcial de Torres son las creaciones de Barcarola "A María" para piano y harmonium (1863) y Romanza sin palabras para violín, violonchelo y piano (1868). De Marcial del Adalid el Cuarteto de cuerdas (1872) y la Sonata para violín y piano (c. 1872). 
élite social, nacional e internacional. Conociendo el elevado grado de complejidad técnica de muchas de las obras, y de acuerdo con los patrones foráneos de comportamiento en la práctica musical de este repertorio, los intérpretes varones adultos de la familia Adalid evitaron la interpretación musical pública y de carácter formal en la que jugarse el prestigio y el honor personal. Por consiguiente, focalizaron su práctica musical en la esfera privada, íntima, informal y doméstica de los salones de sus casas y palacios, abriéndose sólo a un círculo reducido de familiares, amigos y músicos profesionales residentes en la ciudad. Un tipo de musicking que se centraba en el acto de la participación musical informal y en la experiencia social que este generaba y que, por lo tanto, implicaba que la impresión de cualquier marca sobre las caras y lujosas partituras se convirtiera en un acto totalmente innecesario y baldío.

Todo este entramado cultural justifica la necesidad sonora de las obras del fondo musical -pese a su principal invisibilidad ante el gran público- pero no prueba su sonoridad. Tal vez deberíamos plantearnos la posibilidad de que la biblioteca musical fuese sonora e insonora al mismo tiempo, como una biblioteca de libros en la que se difundían discursos, circulaban ideas, se leía privada o colectivamente y era exhibida físicamente como un objeto. Gran parte de la música del fondo pudo ser tocada sin la necesidad de plasmar sobre sus folios marca alguna, como se ha podido demostrar gracias a la única prueba concluyente sobre su interpretación pública. Paralelamente, era exhibida físicamente en los salones de sus palacios como un objeto caro y de lujo, como símbolo del elevado estatus social de sus dueños. De acuerdo con estos fines también era exhibida a cargo de músicos profesionales en performances abiertas y públicas y bajo patrocinio del gremio de comerciantes, del que los Adalid eran y pretendían ser, con este tipo de actos, miembros destacados.

El fondo musical Torres y las pautas de comportamiento cultural que siguieron sus creadores para confeccionarlo y practicarlo, son similares a las usadas por los Adalid en su fondo. Por consiguiente, y aunque por el momento no han aparecido en España otros fondos musicales físicos y coetáneos a los creados por los varones de estas dos ramas familiares, podríamos aventurar que existieron ciertos círculos de la élite social española de la primera mitad del siglo XIX que siguieron patrones culturales similares en lo competente a este tipo de coleccionismo y práctica musical ${ }^{72}$.

72. Cuando empleamos el término de fondo musical físico, nos referimos a fondos musicales que existan en la actualidad, que no hayan desaparecido y de los que se conserve algo más que un inventario de obras. 


\section{Anexo. Abreviaturas de las siglas de los archivos citados}

Archivo de la Colegiata de A Coruña (ACC).

Archivo General Militar de Segovia, (AGMS).

Archivo Histórico del Reino de Galicia, (AHRG).

Archivo Municipal de La Coruña, (AMC).

Archivo Notarial de La Coruña, (ANC).

Archivo Pazo de Vila Suso. Fondo Torres Adalid (APV Torres Adalid).

Biblioteca da Real Academia Galega, (BRAG). 